\title{
Understanding Medical Service OUtshopping: Can Psychographics Enhance Understanding?
}

\author{
Robert A. Swerdlow \\ Mark Guidroz \\ Marleen Roosth Swerdlow \\ Lamar University \\ Beaumont, Texas
}

The two spatial aspects of consumer shopping behavior, intramarket and intermarket patronage, have been widely studied by researchers. Intramarket patronage, deals with the movement of consumers within a local market and is of particular interest when selecting retail shopping sites, while intermarket patronage or "outshopping," deals with the movement of consumers between or among markets. In addition to being an important factor in choosing retail sites, it also influences the overall rate of sales for particular markets and contributes to establishing trade area boundaries ([8], p. 200).

Outshopping has intrigues theorists since markets were first studied [8]. In practical terms, outshopping results in the transfer of retail revenues and profits from small to large centers and "is one of the key determinants of the overall health of the economic base" $([15]$, p. 3$)$ of the area.

In their studies of the spatial aspects of consumer shopping behavior, market researchers have mainly focused on the purchase of products as opposed to services. Furthermore, very few have directly examined the process of consumers who shop for medical services outside of their local trade area ([1], p. 173). Health care in the United States is currentiy experiencing a vast restructuring process, and is beginning to change the role of consumers. Furthermore, "the industry, has changed dramatically in the past 10 years due to a variety of governmental, economic, demographic, and professional factors" ([6], p. 27), and detailed studies of the impacts that these changes have made on the consumer segment are merited.

Good health and the quality of health care services are extremely high in the priorities of most Americans. Health care is one of the largest industries in the country, and much of its growth can be accounted for in the period from 1960 to 1984. During this time, Americans increased their expenditures for health care services from $\$ 26.9$ billion dollars per year to $\$ 387.4$ billion dollars per year ([4], p. 96). Translated into Gross National Product (GNP) figures, in 1960 our health care expenditures accounted for 5.3 percent of the GNP, and by 1984, it had doubled to 10.6 percent of the GNP ([4], p. 96).

Currently, health care providers whose costs exceed the Diagnostic Related Groups (DRGs), must pay for the differences. This development has not only made health

Journal of Business Strategies, Volume 6, Number 2 (Fall 1989) 
care providers more cost efficient, but has also forced them to be more competitive. Recognizing this, "professionals in the health care industry are beginning to realize that understanding the needs and wants of the target group for any health care service is vital." ([16], p. 9) This idea is also supported by researchers who noted that this approach "represents a coordinated effort to establish a management system that effectively links the institution with all the elements of its service community." ([17], p. 75)

Two authors felt that during the 1980 s the health care industry would see consumers address "issue of cost, quality, and access" to include "shopping for healthcare services" ([7], p. 76). It was observed that consumers "want more information about products and services, and they are likely to take advantage of health care alternatives that offer them convenience and quality at a reasonable cost." ([12], p. 36) Furthermore, it was stated that today's health care consumer is "more likely to get second opinions, shop around for specialized medicine, and even travel to other communities for medical care without a referral from a doctor." ([12], p. 36)

The earliest works dealing with the spatial movements of consumers are classified as macro-analytical because they deal with market characteristics, rather than consumers, and attempt to determine trade area boundaries. The first writing on the subject of the movement of consumers between markets was authored by William J. Reilly [14], followed by Converse [5] and Huff [10].

The more current research on intermarket patronage has focused on the consumer characteristics of the particular market. These studies are classified as microanalytical and mostly deal with a consumer's demographics, psychographics, and attitudes. The results of these studies have provided various measurements of inshopping and outshopping and have formulated descriptive profiles of the consumer groups ([8], p. 201).

\section{Products and Outshopping}

The majority of the earlier micro-analytical research has been concerned with consumers who purchase products outside of their local trade area, and has not tested the intermarket patronage of services. In their 1968 article, Herrmann and Beik [9] collected data about out-of-town shopping patterns from a survey of the residents of State College, Pennsylvania. The researchers defined an outshopper as one who hed shopped outside a five mile radius of the downtown area at least one time during the previous year. It was found that 71.4 percent had shopped out-of-town in the previous year. Among this outshopper group, the median number of trips made was three, more often among higher income families, those who possessed out-of-town charge accounts, as well as those families with older of fewer children.

Thompson [19] conducted two intermarket patronage studies in Georgia. In both studies, he considered an outshopper to be one who made at least one purchase outof-town in the last six months. In the first study, the data were provided by 340 permanent residents of the city of Athens, a university town, located about 70 miles from Atlanta. Of the respondents, 61 percent had shopped out-of-town at some time 
within the six months prior to the survey. The median number of outshopping trips was three, over 75 percent chose Atlanta as their shopping location, it was most prevalent among high income groups, highly educated groups, younger families, and families holding out-of-town charge accounts. The most commonly given reasons for outshopping were poor selection, high prices, and parking problems of the local trade area.

The data for the second Thompson study [18] were provided by 1,543 consumers who resided in ten towns in counties which generally lie to the south and west of Augusta, Georgia. The level of consumer outshopping in the study area was found to be over 84 percent. In addition, almost 64 percent of the respondents reported that they had shopped out-of-town six or more times in the prior six months. Almost twothirds of the respondents chose Augusta as their outshopping location. The research profiled an outshopper as one who was more likely to be younger, white, earn a higher income, and possess an out-of-town charge account. Local conditions with which outshoppers were most dissatisfied proved to be the same as in Thompson's first study.

In addition to the product categories studied, Samli, Riecken, and Yavas [15] included several service categories in their outshopping analysis which was published in 1983. The service categories studied were barber/beauty shops, dry cleaning, automobile repair, television and radio repair, medical, dental, and insurance. Two hundred questionnaires were obtained by a telephone survey from a small Midwestern community situated within twenty miles of two larger trading areas for the analysis. They found that "various products and services for which convenience would be important (including professional services) are predominately bought in the local facilities." ([15], p. 9)

In a study of intermarket patronage, six service categories in addition to several product categories were studied. Researched were insurance, legal, accounting, banking, medical, and dental services. It was found that legal, insurance, and accounting services were purchased significantly more out of a Southwestern MSA than the other service categories [2].

Recently, two articles have been published that deal specifically with medical services outshopping, although both deal with rural consumers. The first study was conducted by the National Research Corporation for Modern Healthcare [11]. The research firm interviewed 1,500 consumers in non-metropolitan areas and found that 42 percent did not believe specialized and suphisticated medical services existed in their areas. Also, 30 percent of those surveyed revealed that they had to go to large metropolitan areas to receive medical care. Furthermore, while 78 percent of the total sample believed adequate medical facilities were available in their areas, only 57 percent believed their communities offered all the services needed.

In addition to the above findings, the report also stated that 47 percent of the rural consumers go to other areas for specialized care, such as cardiac and cancer treatment, or for women's services. Also, 10 percent left their local trade area for surgery and 15 percent for hospitalization [11]. 
The second recent study focused on rural consumers who purchase medical services from physicians outside of their local trade areas. The study was conducted in a rural, agricultural community in Iowa, and yielded a sample of 216 household for the analysis. The dependent variable was defined as shopping outside of the local trade area for medical services within a one year time frame [1].

The findings indicated that the rural medical outshopper was more dissatisfied than the medical inshopper with local medical services, the competence of the local physicians, the fees physicians charge, the waiting time in the physician's office, and experiences with other local office personnel such as nurses. Also, when medical outshoppers were compared to medical inshoppers, the outshopping group was more likely to think that the local office did not have adequate equipment, that the health care needs of the local community were not being met and that they should see the same physician on successive visits [1].

\section{Research Design}

The objective of this study was to formulate a medical service outshopper profile for a specific geographic area. The study used a sample of consumers in order to gain information concerning their medical service purchases, outshopping behavior, attitudes, life-styles, and demographics. A Southwestern Metropolitan Statistical Area (MSA) was the specific geographic area studied. The MSA is a three county area with a total population of 394,700 ([13], p. 87).

A questionnaire, which measured four major areas of study, was employed as the data collection instrument for this study. It included questions on the respondents' outshopping behavior, attitudes, psychographics, and demographics. After the questionnaires were completed, statistical analysis of the data was performed to discover any relationships that existed among the four areas of the survey instrument.

In order to obtain a 95 percent level of confidence in estimating the percentage of consumers who outshop for medical services in the MSA studied, at least 307 completed questionnaires were needed according to a normal sample size determination formula ([3], p. 321). There were 359 usable questionnaires completed.

\section{Data Analysis}

\section{Outshopping Behavior}

Of the 359 people responding to the questionnaire, $64(17.8 \%)$ had not shopped outside of the MSA in the past twelve months. Fifty respondents (13.9\%) had shopped outside of the area once, $68(18.9 \%)$ twice, $29(10.9 \%)$ three times, and 20 of the respondents (5.6\%) had shopped outside their local MSA four times. The plurality of the respondents $(107$, or $29.8 \%$ ) had outshopped over four times in the past year. Finally, nine respondents $(2.5 \%)$ were unsure of the proper response and 2 respondents $(.6 \%)$ did not provide a response.

Among selected non-medical professional services purchased by respondents within the past 12 months, insurance services (15.9\%) and banking services (13.9\%) were 
purchased more often than legal services $(6.7 \%)$, dental services $(6.7 \%)$, or accounting services (5.3\%) outside of the MSA.

With respect to medical services (excluding emergency care) purchased by households outside of the MSA in the past two years, the results indicated that 91 (25.3\%) of the respondents had outshopped for medical services while $267(74.4 \%)$ had not. One respondent indicated not sure. This pool of 92 medical outshopper respondents serves as the basis for analysis in the following section.

\section{Medical Services Outshopping}

Of the 92 respondents identified as medical outshoppers within the past two years, $11(12 \%)$ had not outshopped for medical services in the past year, $27(29.3 \%)$ had outshopped once, $16(17.4 \%)$ had outshopped twice, $12(13 \%)$ had outshopped three times, and seven (7.6\%) had outshopped four times. Eighteen of the respondents (19.6\%) had outshopped for medical services more than four times in the past year, with one respondent not sure.

The next series of medical outshopping questions related to the respondents' most recent medical service purchase outside of the MSA. First, respondents were queried on the factor which most influenced their decision to make their most recent medical service purchase out of the MSA. A physician's recommendation of referral was listed by $31(33.7 \%)$ of the medical service outshoppers as the factor that influenced them the most, while 29 (31.5\%) said that their decision to outshop for medical services was based on a personal or family decision. A decision based on a recommendation from a friend or a relative was identified by $22(23.9 \%)$ of the respondents as the determining factor, while only two of the medical outshoppers $(2.2 \%)$ felt that their insurer influenced them the most to leave the MSA area to purchase medical services. Ten respondents (10.8\%) listed other factors.

Asked if the medical service they most recently purchased out of the area could have been purchased in the MSA, the majority of the outshoppers (51, or $55.4 \%$ ), reported that the service could have been purchased in their local MSA, while 27 (29.3\%) said the service could not have been purchased in the local area. Fourteen $(15.3 \%)$ of the outshoppers were not sure if the service was available in their local MSA.

Frequency distribution analysis on the full 359-respondent pool was performed for those questions which sought to determine attitudes toward several factors related to medical services. Asked if they believed the MSA area offers all the medical services they and members of their households need, the majority of the respondents (209, or $58.2 \%$ ), felt that the MSA had the medical services they and members of their households need. On the other hand, $92(25.6 \%)$ did not think that the local area had all the medical services they required, while $52(14.5 \%)$ of the respondents were not sure.

Respondents were asked to rank the importance of ten salient attributes of health care when selecting a medical service. The respondent ranked each of these attributes on a five point Likert scale. The first health care attribute studied was "Modern 
Physical Appearance of Facilities." Of the 359 people responding, $149(41.5 \%)$ felt that this attribute was very important, $135(37.6 \%)$ thought it was slightly important, and $58(16.2 \%)$ were neutral. A listing of the ten points polled and their results are presented in Table 1.

Table 1

Respondent's Attitude Toward Salient Health Care Attributes When Choosing a Medical Service by Frequency and Percent

Response:

\begin{tabular}{cccccc} 
& $\begin{array}{c}\text { Very } \\
\text { Important }\end{array}$ & Neutral & $\begin{array}{c}\text { Slightly } \\
\text { Unimportant }\end{array}$ & Nery & No \\
Scale Value: & 5 & 4 & 3 & 2 & 1 \\
\hline
\end{tabular}

Health Care Attribute

Modern Physical Appearance

of Facilities $149(41.5 \%) \quad 135(37.6 \%) \quad 58(16.2 \%) \quad 5(1.4 \%) \quad 7(1.9 \%) \quad 5(1.4 \%)$

Clean

Facilities

$$
343(95.40)
$$

$2(0.600)$

$-\quad 2(0.60)$

Reputable Physicians and

Specialists $\quad 339(94.40)$

$14(3.900) \quad 3(0.800)$

$\begin{array}{lll}- & 2(0.60) & 1(0.30)\end{array}$

Knowledgeable

Staffs

$$
326(90.80) \quad 24(6.700) \quad 6(1.700)
$$$$
-\quad 3(0.80)
$$

Friendly

Staffs

$$
242(67.40)
$$

$17(4.700)$

$2(0.60)$

Latest Medical Technology

Available

$303(84.20)$

$44(12.30)$

$6(1.700)$

$-4(1.10)$

Prompt

Treatment

$$
316(88.00)
$$

$$
-4(1.10)
$$

Free and Ample

Parking $132(36.80) \quad 110(30.60)$ $86(24.00) \quad 23(6.40)$

Convenience to

My Home $125(34.80)$ $127(35.40)$ $74(20.60)$ $18(5.00) \quad 14(3.90)$

Reasonable

Prices $231(64.40)$ $77(21.40)$ $38(10.60)$ $7(1.90)$ $6(1.70)$ 


\section{Psychographic Variables}

The next section of the questionnaire tested a new area in medical services outshopping research-psychographics. This section included 15 variables which sought to determine the respondents' life-style characteristics which were related to health care. To make it possible for this data to be presented in a concise table format, the following codes will be used in Table 2 for the variables listed on the questionnaire.

Table 2

\section{Psychographic Variables Considered}

Code Psychographic Variable Listed on Questionnaire

\begin{tabular}{|c|c|}
\hline & Do You: \\
\hline A & Have a yearly medical checkup or physical? \\
\hline B & Currently have a membership in a health club or spa? \\
\hline $\mathrm{C}$ & $\begin{array}{l}\text { Currently receive your medical services through a Health Maintenance } \\
\text { Organization (HMP) or a Preferred Provider Organization (PPO)? }\end{array}$ \\
\hline $\mathrm{D}$ & $\begin{array}{l}\text { Read (a) medical or healthcare/fitness related book(s), magazine(s), } \\
\text { journal(s), or newsletter(s) regularly? }\end{array}$ \\
\hline $\mathrm{E}$ & Read the medical column in the newspaper regularly? \\
\hline F & Watch healthcare/fitness television programs regularly? \\
\hline G & Smoke cigarettes or use some form of tobacco regularly? \\
\hline $\mathrm{H}$ & Exercise or participate in a sport regularly? \\
\hline I & Take vitamins or nutritional supplements regularly? \\
\hline $\mathbf{J}$ & Usually maintain a healthy/nutritional diet? \\
\hline $\mathrm{K}$ & Currently have some form of health insurance? \\
\hline \multirow[t]{2}{*}{ L } & Currently have a family physician in the MSA area? \\
\hline & Have You: \\
\hline M & $\begin{array}{l}\text { Ever purchased medical services from a free standing unit (Medi-Quick, } \\
\text { Statcare, etc.) as opposed to a hospital emergency room or physician's } \\
\text { office? }\end{array}$ \\
\hline N & $\begin{array}{l}\text { Seen, read, or heard an advertisement for a hospital, care center, or } \\
\text { physician within the past month? }\end{array}$ \\
\hline 0 & $\begin{array}{l}\text { Ever purchased medical services from a hospital in the MSA area for } \\
\text { you or a member of your household? }\end{array}$ \\
\hline
\end{tabular}

Results of these topical responses are presented below in Table 3. Briefly, of the 359 respondents, the majority reported that they did have a medical checkup or physical each year (66.3\%), exercised or participated in a sport regularly $(60.4 \%)$, took vitamins or nutritional supplements regularly $(50.7 \%)$, usually maintained a healthy/nutritional diet ( $71.9 \%$ ), currently had some form of health insurance ( $88 \%$ ). In addition, most of the respondents had seen, read; or heard an advertisement for a 
hospital, care center, or physician within the past month $(87.4 \%)$, and had purchased medical services from a hospital in the MSA area for themselves or a member of their household (76.9\%).

On the other hand, the majority of the respondents did not currently have a membership in a health club or spa $(72.1 \%)$, did not currently receive their medical services through a HMO or PPO (80.5\%), did not read the medical column in the newspaper regularly $(52.9 \%)$, did not watch health care/fitness television programs regularly (54.6\%), or did not smoke cigarettes or use some form of tobacco regularly (78\%). In addition, most of the people responding to the survey had not purchased medical services from a free standing unit as opposed to a hospital emergency room or physician's office $(61.3 \%)$.

One psychographic variable in which no one response was selected by a majority of the persons completing the survey was identified. One hundred and seventy-four (48.4\%) respondents indicated that they read a medical or health care related book or magazine regularly, while $173(48.2 \%)$ did not. In addition, $11(3.1 \%)$ respondents were not sure, and one $(0.3 \%)$ did not answer the question.

\section{Table 3}

Health Care Related Psychographic Characteristics of Respondents By Frequency and Percent

\begin{tabular}{lrrrr} 
Code & Yes & No & Not Sure & No Response \\
\hline A & $238(66.3 \%)$ & $116(32.3 \%)$ & $4(1.1 \%)$ & $1(0.3 \%)$ \\
B & $98(27.30)$ & $259(72.10)$ & $2(0.60)$ & - \\
C & $21(5.800)$ & $289(80.50)$ & $43(12.0)$ & $6(1.70)$ \\
D & $174(48.40)$ & $173(48.20)$ & $11(3.10)$ & $1(0.30)$ \\
E & $164(45.70)$ & $190(52.90)$ & $4(1.10)$ & $1(0.30)$ \\
F & $145(40.40)$ & $196(54.60)$ & $13(3.60)$ & $5(1.40)$ \\
G & $74(20.60)$ & $280(78.00)$ & $4(1.10)$ & $1(0.30)$ \\
H & $217(60.40)$ & $135(37.60)$ & $6(1.70)$ & $1(0.30)$ \\
I & $182(50.70)$ & $174(48.50)$ & $3(0.80)$ & - \\
J & $258(71.90)$ & $80(22.30)$ & $17(4.70)$ & $4(1.10)$ \\
K & $316(88.00)$ & $39(10.90)$ & $3(0.80)$ & $1(0.30)$ \\
L & $296(82.50)$ & $59(16.40)$ & $3(0.80)$ & $1(0.30)$ \\
M & $136(37.80)$ & $220(61.30)$ & $2(0.60)$ & $1(0.30)$ \\
N & $314(87.40)$ & $38(10.60)$ & $6(1.70)$ & $1(0.30)$ \\
O & $276(76.90)$ & $80(22.30)$ & $3(0.80)$ & -
\end{tabular}

\section{Demographic Variables}

The final section of the questionnaire was comprised of 11 demographic questions. These questions sought to determine the respondents' sex, marital status, occupation, age, education, and number of dependent children in the household. Also included were questions pertaining to home ownership, length of residence in the MSA, number of individuals employed in the household, and level of income. The full 359-resondent 
pool statistically mirrored the area studied with regard to demographic variables.

\section{Outshopping Characteristics}

Using Chi-Square analysis, outshopping for medical services proved to be signifcantly related to outshopping for legal services, banking services, and dental services. First, 16.5 percent of the respondents reported that they had purchased legal services outside of the MSA had also outshopped for medical services, in contrast to only 3.4 percent who had outshopped for legal services, but not for medical services. In addition, 25.3 percent of the respondents who had purchased banking services out of the local area proved to be medical services outshoppers, while medical inshoppers purchased out-of-town banking services only 9.7 percent of the time. Finally, 12.1 percent of the persons who reported purchasing dental services out of the MSA were classified as medical service outshoppers. Only out of the MSA were classified as medical service outshoppers. Only 4.5 percent of those who had not purchased medical services out the local area chose to purchase dental services out of the MSA. These results are presented in Table 4 .

Table 4

Percentage of Respondents by Outshopping for Legal, Banking, and Dental Services vs. Outshopping for Medical Service

\begin{tabular}{lcc} 
& \multicolumn{2}{c}{ Outshopping for Medical Services } \\
\cline { 3 - 3 } Outshopping for: & Yes & No \\
\cline { 1 - 2 } Legal Services & & \\
\cline { 1 - 2 } Yes & $16.5 \%$ & $3.4 \%$ \\
No & 76.0 & 92.0 \\
Not Sure & 7.5 & 4.6 \\
\hline Totals & $100.0 \%$ & $100.0 \%$ \\
\hline \multicolumn{2}{l}{ Level of Significance -.0004} & \\
\hline
\end{tabular}

\begin{tabular}{lcc} 
Banking Services & & \\
\cline { 1 - 1 } Yes & $25.3 \%$ & $9.7 \%$ \\
No & 71.4 & 84.3 \\
Not Sure & 3.3 & 6.0 \\
\hline Totals & $100.0 \%$ & $100.0 \%$ \\
\hline Level of Significance -.0022 & \\
\hline
\end{tabular}

\begin{tabular}{lcc} 
Dental Services & & \\
\cline { 1 - 2 } Yes & $12.1 \%$ & $4.5 \%$ \\
No & 80.2 & 88.8 \\
Not Sure & 7.7 & 6.7 \\
\hline Totals & $100.0 \%$ & $100.0 \%$ \\
\hline Level of Significance -.0004 & \\
\hline
\end{tabular}




\section{Attitude Characteristics}

Three questions on the survey instrument sought to determine the respondents' attitudes toward several health care related factors. The first significant finding in this section is shown in Table 5. While the majority (69.7\%) of medical inshoppers felt that the MSA area offered all the medical services needed by their households, only 30.1 percent of medical outshoppers felt the same way.

\section{Table 5}

\section{Percentage of Respondents by Attitudes Toward Availability of Medical Services vs. Outshopping for Medical Services}

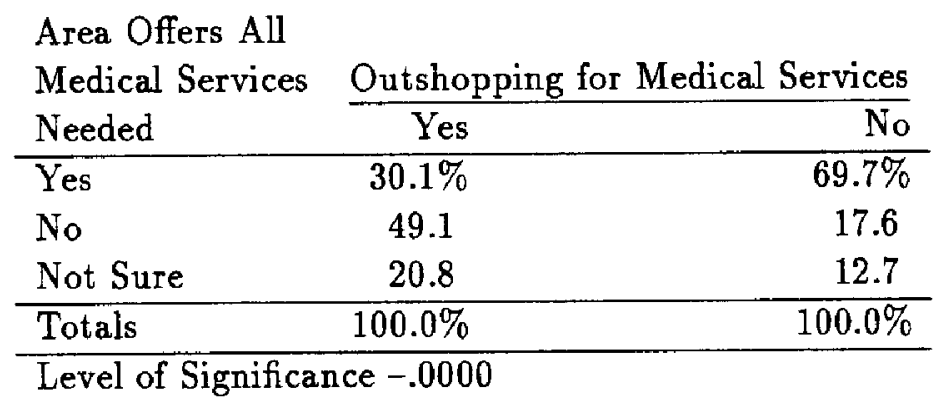

The second attitudinal question studied dealt with the importance that respondents placed on salient attributes when selecting a medical services. Of the ten attributes listed on the questionnaire, two proved to be significantly related to medical services outshopping. Medical service outshoppers ascribed less importance to convenience and reasonable prices as salient attributes of health care than those respondents who purchased their medical services in the MSA. These results are detailed in Table 6.

The final question in this section sought to determine the respondents' attitudes toward the MSA area's medical facilities, services, and personnel. Medical services outshopping was found to have significant relationship with seven out of the ten factors examined. The seven significant factors included; "Modern Physical Appearance of Facilities," "Clean Facilities," "Reputable Physicians and Specialists," "Knowledgeable Staffs,", "Friendly Staffs," "Latest Medical Technology Available," and "Prompt Treatment." Those respondents who were medical services outshoppers indicated that these factors described the local MSA less appropriately than did medical services inshoppers. The results, according to related factors, are illustrated in Table 7. 
Table 6

Percentage of Respondents by Importance Placed on Salient Attributes of Health Care vs. Outshopping for Medical Services

\begin{tabular}{|c|c|c|}
\hline Salient Attribute & Outshopping for & Medical Services \\
\hline of Health Care & Yes & $\mathrm{No}_{\mathrm{O}}$ \\
\hline Convenience to $\mathrm{My} \mathrm{H}$ & & \\
\hline Very Important & $30.8 \%$ & $36.7 \%$ \\
\hline Slightly Important & 23.1 & 39.3 \\
\hline Neutral & 27.5 & 18.4 \\
\hline Slightly Unimportant & 8.8 & 3.7 \\
\hline Very Unimportant & 9.8 & 1.9 \\
\hline Totals & $100.0 \%$ & $100.0 \%$ \\
\hline Level of Significance - & & \\
\hline Reasonable Prices & & \\
\hline Very Important & $53.8 \%$ & $67.8 \%$ \\
\hline Slightly Important & 22.0 & 21.3 \\
\hline Neutral & 16.5 & 8.6 \\
\hline Slightly Unimportant & 5.5 & 0.8 \\
\hline Very Unimportant & 2.2 & 1.5 \\
\hline Totals & $100.0 \%$ & $100.0 \%$ \\
\hline Level of Significance & & \\
\hline
\end{tabular}

Table 7

Percentage of Respondents by Attitudes Toward Medical Facilities of the MSA vs. Outshopping for Medical Services

\begin{tabular}{lrr} 
Medical Service Factor & \multicolumn{2}{c}{ Outshopping for Medical Services } \\
\cline { 3 - 3 } and Responses & Yes & No \\
\hline Modern Physical Appearance & & \\
of Facilities & & \\
\hline Completely Describes & $16.5 \%$ & $43.4 \%$ \\
Slightly Describes & 47.3 & 39.7 \\
Neutral & 27.5 & 15.4 \\
Usually Does Not Describe & 7.7 & 1.1 \\
Does Not Describe At All & 1.0 & 0.4 \\
\hline Totals & $100.0 \%$ & $100.0 \%$ \\
\hline Level of Significance -.0001 & &
\end{tabular}


Table 7 - continued ( 1 )

Percentage of Respondents by Attitudes Toward Medical Facilities of the MSA vs. Outshopping for Medical Services

\begin{tabular}{lrr} 
Medical Service Factor & Outshopping for Medical Services \\
\cline { 3 - 3 } and Responses & Yes & No \\
\hline Clean Facilities & $23.1 \%$ & $55.8 \%$ \\
\cline { 1 - 2 } Completely Describes & 31.9 & 37.8 \\
Slightly Describes & 19.8 & 5.2 \\
Neutral & 19.8 & 0.8 \\
Usually Does Not Describe & 5.4 & 0.4 \\
Does Not Describe At All & $100.0 \%$ & $100.0 \%$ \\
\hline Totals & & \\
\hline Level of Significance -.0000 &
\end{tabular}

Reputable Physicians/Specialists

\begin{tabular}{lrr}
\hline Completely Describes & $2.8 \%$ & $53.6 \%$ \\
Slightly Describes & 20.9 & 33.0 \\
Neutral & 29.7 & 11.2 \\
Usually Does Not Describe & 30.1 & 2.2 \\
Does Not Describe At All & 16.5 & - \\
\hline Totals & $100.0 \%$ & $100.0 \%$ \\
\hline Level of Significance -.0000 & & \\
\hline
\end{tabular}

Knowledgeable Staffs

\begin{tabular}{lrr}
\hline Completely Describes & $3.3 \%$ & $43.4 \%$ \\
Slightly Describes & 33.0 & 40.4 \\
Neutral & 37.3 & 13.9 \\
Usually Does Not Describe & 15.4 & 2.3 \\
Does Not Describe At All & 11.0 & - \\
\hline Totals & $100.0 \%$ & $100.0 \%$ \\
\hline Level of Significance -.0006 & &
\end{tabular}

Friendly Staffs

\begin{tabular}{lrr}
\hline Completely Describes & $14.2 \%$ & $45.3 \%$ \\
Slightly Describes & 26.4 & 37.8 \\
Neutral & 45.1 & 15.8 \\
Usually Does Not Describe & 6.6 & 1.1 \\
Does Not Describe At All & 7.7 & - \\
\hline Totals & $100.0 \%$ & $100.0 \%$ \\
\hline Level of Significance - -.0013 & & \\
\hline
\end{tabular}


Table 7 - continued (2)

Percentage of Respondents by Attitudes Toward Medical Facilities of the MSA vs. Outshopping for Medical Services

\begin{tabular}{lrr} 
Medical Service Factor & \multicolumn{2}{c}{ Outshopping for Medical Services } \\
\cline { 2 - 3 } and Responses & Yes & No \\
\hline Latest Medical Technology & & \\
Available & $2.2 \%$ & $37.8 \%$ \\
\hline Completely Describes & 26.4 & 43.4 \\
Slightly Describes & 40.6 & 12.0 \\
Neutral & 19.8 & 4.1 \\
Usually Does Not Describe At All & 11.0 & 1.2 \\
Does Not Describe At All & - & 1.5 \\
No Response & $100.0 \%$ & $100.0 \%$ \\
\hline Totals & & \\
\hline Level of Significance - -.0000 & & $35.3 \%$ \\
\hline & & 33.0 \\
Prompt Treatment & $13.1 \%$ & 21.7 \\
\hline Completely Describes & 28.6 & 5.2 \\
Slightly Describes & 36.3 & \\
Neutral & 11.0 & 1.1 \\
Usually Does Not Describe & 3.7 & \\
Does Not Describe At All 11.0 & - & \\
No Response & $100.0 \%$ & \\
\hline Totals & & \\
\hline Level of Significance - .0006 & & \\
\hline
\end{tabular}

\section{Psychographic Characteristics}

Three of the 15 psychographic variables tested on the survey instrument proved to be significantly related to medical service outshopping as a result of further ChiSquare analysis performed. First, the respondents who were classified as medical services outshoppers were more likely to have a current membership in a health club or spa $(36.3 \%)$ than medical inshoppers $(24.3 \%)$. Second, a greater percentage of medical services outshoppers $(24.2 \%)$ reported not currently having some type of health insurance than the group of consumers who chose to purchase medical services in the MSA (10.1\%). Finally, outshoppers of medical services were more likely not to currently have a family physician in the MSA $(28.6 \%)$ than medical inshoppers $(12.4 \%)$. These results are presented in Table 8. 
Table 8

Percentage of Respondents by Psychographic Characteristics vs. Outshopping Medical Services

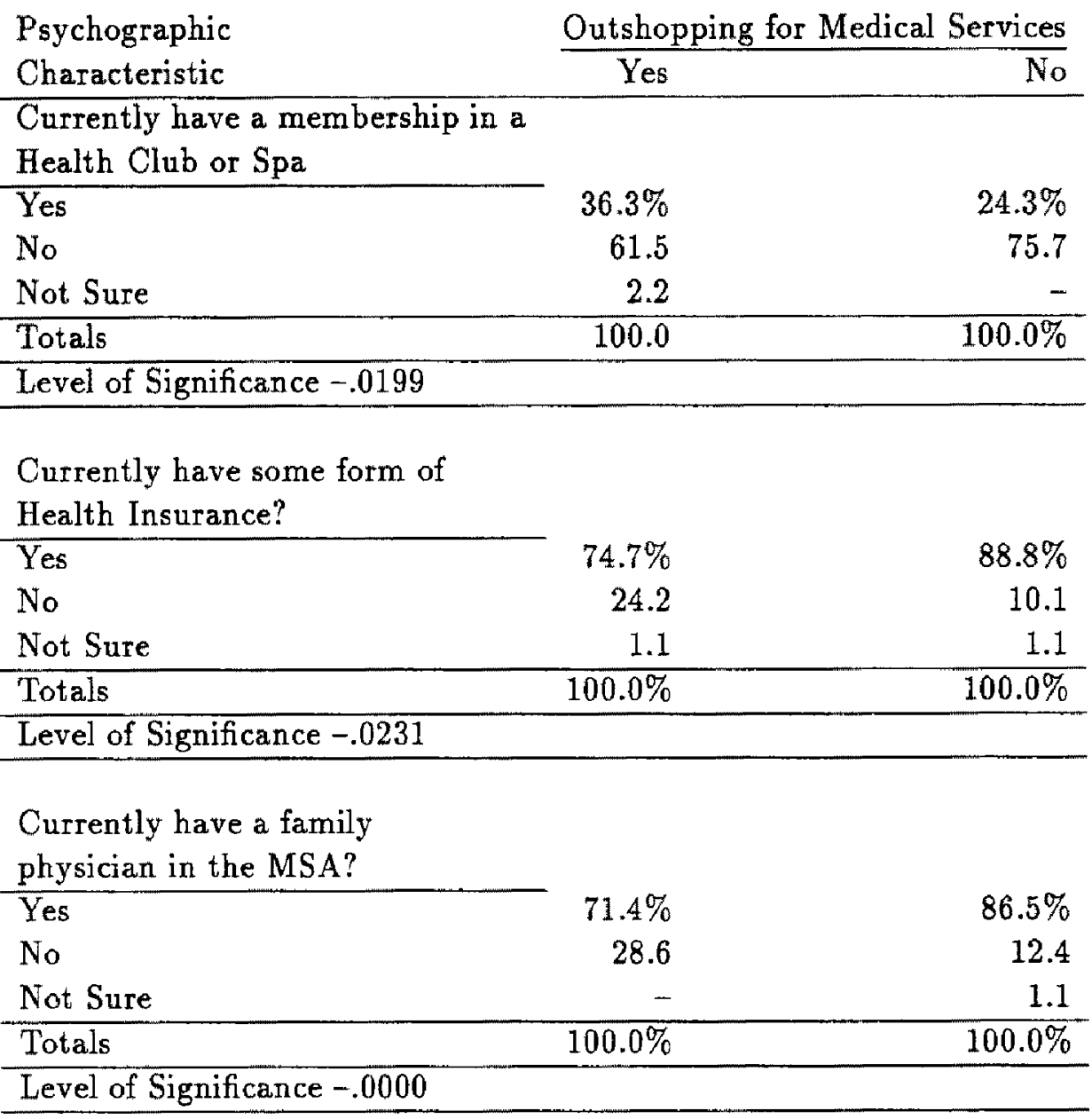

\section{Conclusions}

The conclusions drawn from the data collected can be summarized as follows:

- Outshoppers for medical services lived in the MSA a shorter period of time than inshoppers.

- Outshoppers were more likely to have a current membership in a health club or spa.

- Outshoppers were less likely to have health insurance, or a family physician.

- Medical outshoppers felt the home MSA did not offer all the medical services needed and were less concerned with convenience and reasonable prices. 
- Outshoppers felt the home MSA did not have as positive feelings regarding Salient characteristics of the medical facilities/providers or did inshoppers.

- The medical outshoppers held negative views of local medical facilities, personnel, and services.

The area of medical outshopping deserves significant further study. For regional medical centers grow, outshopping from surtounding areas will have to flourish. Marketing health care services, both within and outside of a geographical area, will clearly be of greater importance as the industry of regional medical centers develops further in these coming years.

More generally, as regional service centers for all industries develop and grow, detailed knowledge of how consumers perceive quality, combined with the relationship between perceived quality and consumer characteristics, will become increasingly important. Once these perceptions and relationships are identified and understood, firms and regions may more effectively and efficiently develop strategic niches for their enterprise.

\section{References}

1. Andrus, David and Frank J. Kohout. "The Effect of Rural Consumer Satisfaction on Outshopping for Medical Services." Health Marketing Quarterly, Vol. 2 (Spring and Summer 1985).

2. Beckcom, Lisa Hooks and Robert A. Swerdlow. "Intermarket Patronage: A Consumer Oriented Approach." Proceedings, Decision Science Institute, 1986.

3. Boyd, Harper W. Jr., Ralph Westfall, and Stanley F. Stasch. Marketing Research: Text and Cases. Homewood, IL: Richard D. Irwin, Inc. (1981).

4. Bureau of the Census. Statistical Abstract of the United States, 1986. Washington, DC: U. S. Department of Commerce (1986).

5. Converse, P. D. "New Laws of Retail Gravitation." Journal of Marketing, Vol. 14 (October 1949).

6. Elsesser, Janice M. "Prognosis for Marketing Research in Health-care Industry: Excellent." Marketing News, May 25, 1984.

7. Evans, Jay and Daniel L. Galles. "Consumer Attitudes Increase Buyer Sophistication." Healthcare Financial Management, Vol. 36 (December 1982).

8. Hawes, Jon M. and James R. Lumpkin. "Understanding the Outshopper." Journal of the Academy of Marketing Science, Vol. 12 (Fall 1984).

9. Herrmann, Robert O. and Leland L. Beik. "Shoppers' Movements Outside Their Local Retail Area." Journal of Marketing, Vol. 32 (October 1968). 
10. Huff, David. "Defining and Estimating a Trading Area." Journal of Marketing, Vol. 28 (July 1964).

11. Jensen, Joyce. " $42 \%$ of Rural Residents are Traveling to Urban Areas for Medical Treatment." Modern Healthcare, December 8, 1985.

12. Jensen, Joyce. "Health Care Alternatives." American Demographics, Vol. 8 (March 1986).

13. "Population." Sales and Marketing Management. October 27, 1986.

14. Reilly, William J. The Law of Retail Gravitation. New York, NY: William J. Reilly (1931).

15. Samli, A. Coskun, Glen Riecken, and Ugar Yavas. "Intermarket Shopping Behavior and the Small Community: Problems and Prospects of a Widespread Phenomenon." Journal of the Academy of Marketing Science, Vol. 11 (Winter 1983).

16. Scammon, Debra and Jon Kennard. "Improving Health Care Strategy Planning Through Assessment of Perceptions of Consumers, Providers and Administrators." Journal of Health Care Marketing, Vol. 3 (Fall 1983).

17. Swerdlow, Robert and Larry T. Patterson. "The Health Care Industry-A Case For The Marketing Concept." Appalachian Business Review, Vol. 8, No. 1 (1981).

18. Thompson, John R. "Characteristics and Behavior of Out-Shopping Consumers." Journal of Retailing, Vol. 47 (Spring 1971).

19. Thompson, John R. "Shopper Mobility." Atlanta Economic Review, Vol. 21 (January 1971). 